\title{
PENINGKATAN KEMAMPUAN MENULIS TEKS EKSPOSISI DENGAN MENGGUNAKAN STRATEGI THINK-TALK-WRITE
}

\author{
Deni Rosdiana \\ SMA Negeri 1 Jalaksana \\ denirosdiana@gmail.com
}

\begin{abstract}
This study aims to (1) improve the quality of the process of learning to write exposition text students of grade X MIPA 5 of SMA Negeri 1 Jalaksana with a ThinkTalk-Write strategy; and (2) to improve the quality of learning outcomes in writing text exposition students in grade $\mathrm{X}$ MIPA 5 of SMA Negeri 1 Jalaksana with a ThinkTalk-Write strategy. This research is Classroom Action Research (CAR) with a qualitative descriptive technique carried out in the X-Mathematics class 5 of SMA Negeri 1 Jalaksana. Retrieval of research data using planning procedures, actions, observations, and reflections. The results of this study prove that the exposition text writing skills of XMIPA 1 grade students of SMA Negeri 1 Jalaksana have increased after learning to write exposition text using Think-Talk-Write strategies. The test results of writing exposition text in the first cycle showed an average value of 77.42 and in the second cycle showed an average value of 84.06 . From these results it can be seen the increase in students' skills in writing exposition text from cycle I to cycle II of 6.64 points or $18.44 \%$. In addition to improving skills, the behavior of students of class X-MIPA 5 of SMA Negeri 1 Jalaksana also experienced a change in a more positive direction after learning to write exposition text using Think-Talk-Write strategies.
\end{abstract}

Keywords: Writing exposition text, Think-Talk-Write Strategy

\begin{abstract}
ABSTRAK
Penelitian ini bertujuan untuk (1) meningkatkan kualitas proses pembelajaran menulis teks eksposisi siswa kelas X MIPA 5 SMA Negeri 1 Jalaksana dengan strategi ThinkTalk-Write; dan (2) untuk meningkatkan kualitas hasil pembelajaran menulis teks eksposisi siswa kelas X MIPA 5 SMA Negeri 1 Jalaksana dengan strategi ThinkTalk-Write. Penelitian ini berjenis penelitian Tindakan Kelas (PTK) dengan teknik deskriptif kualitatif yang dilaksanakan di kelas X-MIPA 5 SMA Negeri 1 Jalaksana. Pengambilan data penelitian menggunakan prosedur perencanaan,tindakan,pengamatan, dan refleksi. Hasil dari penelitian ini membuktikan bahwa keterampilan menulis teks eksposisi pada siswa kelas XMIPA 1 SMA Negeri 1 Jalaksana mengalami peningkatan setelah dilakukan pembelajaran menulis teks eksposisi dengan strategi Think-Talk-Write. Hasil tes menulis teks eksposisi pada siklus I menunjukkan nilai rata-rata 77,42 dan pada siklus II menunjukkan nilai rata-rata 84,06. Dari hasil tersebut dapat diketahui peningkatan keterampilan siswa dalam menulis teks eksposisi dari siklus I ke siklus II sebesar 6,64 poin atau 18,44\%. Selain peningkatan keterampilan, perilaku siswa kelas X-MIPA 5 SMA Negeri 1 Jalaksana juga mengalami perubahan ke arah yang lebih positif setelah dilakukan pembelajaran menulis teks eksposisi dengan strategi Think-Talk-Write.
\end{abstract}

Kata Kunci : MenulisTeks eksposisi, Strategi Think-Talk-Write

\begin{tabular}{l|l|l} 
Submitted Apr 15, 2020 & Revised May 18, 2020 & Accepted May 23, 2020
\end{tabular}

\section{Pendahuluan}

Perkembangan kurikulum 2013 menuntut siswa untuk memiliki kemampuan berpikir dan bertindak produktif dan kreatif. Permendikbud 59 tahun 2014 menguraikan bahwa kurikulum 2013 berpusat pada pola pembelajaran yang berpusat pada siswa dan interaktif. Kurikulum 2013 dikembangkan dengan penyempurnaan pola belajar sendiri dan kelompok dengan tetap memperhatikan pengembangan potensi khusus yang dimiliki setiap siswa. Salah 
satunya adalah kemampuan siswa menulis berbagai macam teks dalam pembelajaran Bahasa Indonesia. Sesuai dengan kompetensi dasar mata pelajaran Bahasa Indonesia yang harus dikuasai oleh siswa Sekolah Menengah Atas kelas X yakni menulis teks anekdot, eksposisi, laporan hasil observasi, prosedur kompleks, dan negosiasi yang koheren, sesuai dengan karakteristik teks yang akan diproduksi baik secara lisan maupun tulisan.

Menulis adalah proses menyampaikan pesan (ide, gagasan, pendapat, informasi dan pengetahuan) secara tertulis yang disampaikan kepada orang lain (Hairuddin,dkk, 2007). Dengan kemampuan menulis, seseorang dapat menuangkan pemikiran atau perasaanya dalam sebuah tulisan sehingga keterampilan menulis sangat bermanfaat (Cintiandini, Nahdi, \& Susilo, 2019). Menulis merupakan suatu keterampilan berbahasa yang dipergunakan untuk menuangkan ide atau gagasan yang ada dalam pikiran melalui bahasa tulisan sehingga dapat dibaca dan dipahami orang lain (Yunsirno, 2010). Menulis merupakan keterampilan berbahasa yang memiliki peran sangat penting dalam dunia pendidikan. Menulis melibatkan berbagai aspek kebahasaan yang meliputi: penggunaan tanda baca dan ejaan, penggunaan diksi, penataan kalimat, pengembangan paragraf, pengolahan gagasan, dan pengembangan model karangan (Ibrahim dan Wahyuni, 2012). Menulis dapat membuat peserta didik terbiasa menyusun tulisan berupa kata-kata yang membentuk kalimat, kumpulan kalimat membentuk paragraf yang sistematis, logis, dan efektif melalui latihan-latihan penulisan paragraf dalam karangan (Helmawati, Raja \& Samhati, 2014).

Kemampuan menulis dapat dikatakan sebagai kegiatan primer yang bersifat produktif dan kreatif. Meskipun menulis merupakan kegiatan primer, proses kegiatan menulis di SMA Negeri 1 Jalaksana belum optimal. Berdasarkan analisis data yang diperoleh peneliti, siswa kelas X MIPA 5 SMA Negeri 1 Jalaksana pada bulan Agustus 2018, diketahui bahwa siswa kurang berminat pada kegiatan menulis. Hal ini ditunjukkan ketika proses menulis teks eksposisi, siswa kesulitan dalam mengembangkan ide untuk dijadikan tulisan yang utuh. Banyak siswa yang mengalami kesulitan untuk menuliskan materi atau bahan yang akan dijadikan tulisan.

Sejauh ini pembelajaran menulis teks eksposisi di SMA Negeri 1 Jalaksana dilakukan oleh guru/peneliti dengan cara membebaskan siswa untuk memilih topik yang akan ditulis. Namun, hal ini membuat siswa belum dapat menuangkan ide untuk menulis karena pengetahuan siswa masih kurang dan penguasaan kosakata siswa masih minim. Meski pembelajaran menulis teks eksposisi sudah dilaksanakan secara terstruktur, siswa cenderung merasa jenuh dengan proses pembelajaran. Dan diketahui bahwa guru/peneliti masih menggunakan metode ceramah dan pemodelan. Guru/peneliti masih menggunakan metode konvesional.

Berdasarkan hasil penilaian terhadap siswa pada pembelajaran menulis teks eksposisi kelas X MIPA 5 SMA Negeri 1 Jalaksana, diketahui bahwa ketercapaian indikator belum maksimal. Rata-rata nilai yang diperoleh siswa belum mencapai kriteria ketuntasan minimal (KKM) pada aspek menulis teks eksposisi yang telah ditentukan sekolah. KKM pada aspek menulis, yaitu 75. Data tersebut membuktikan bahwa pembelajaran menulis teks eksposisi pada siswa kelas X MIPA 5 SMA Negeri 1 Jalaksana masih rendah. Melihat adanya ketidaksesuaian antara harapan dan kenyataan, maka peneliti melakukan penelitian untuk meningkatkan kemampuan menulis teks, khususnya teks eksposisi. 
Teks eksposisi, menurut Alwasilah (2007), adalah paragraf yang berisi paparan tentang sesuatu yang bermaksud memberitahukan dan bertujuan untuk menjelaskan sesuatu kepada pembaca. Bentuk tulisan faktual yang berupa eksposisi (pemaparan informasi) sangat beragam. Hal ini disebabkan adanya tujuan penulisan eksposisi yang mengarah untuk memberi tahu, mengupas, menguraikan, atau menerangkan sesuatu yang dapat berupa data faktual, misalnya tentang suatu kondisi yang benar-benar terjadi, dan tentang bagaimana sesuatu bekerja. Oleh karena itu, berdasarkan informasi mengenai permasalahan yang muncul terkait kemampuan menulis teks eksposisi pada siswa kelas X MIPA 5 SMA Negeri 1 Jalaksana, maka perlu diadakan penelitian untuk meningkatkan kemampuan menulis teks eksposisi dengan menggunakan strategi yang mendukung.

Strategi Think-Talk-Write (TTW) merupakan salah satu strategi yang diduga dapat meingkatkan kemampuan menulis. Think Talk Write adalah sebuah pembelajaran yang dimulai dengan berpikir melalui bahan bacaan (menyimak, mengkritisi, dan alternatif solusi), hasil bacaannya dikomunikasikan dengan presentasi, diskusi, dan kemudian membuat laporan hasil presentasi (Hamdayama, 2014). Dalam Think Talk Write, perencanaan dari tindakan dilakukan dengan cermat mengenai kegiatan pembelajaran yaitu melalui berpikir, bertukar pendapat, dan menuliskan hasil diskusi agar tujuan pembelajaran dapat tercapai (Iru \& Arihi, 2012). Think-Talk-Write (TTW) mefasilitasi siswa melatih berbahasa secara lisan dan menulis bahasa Indonesia dengan lancar. Strategi ini didasarkan pada pemahaman bahwa belajar adalah sebuah perilaku sosial. Strategi TTW mendorong siswa untuk berpikir, berbicara, dan kemudian menuliskan suatu topik tertentu. Model ini digunakan untuk mengembangkan tulisan dengan lancar dan melatih bahasa sebelum dituliskan. Strategi TTW memperkenankan siswa untuk memengaruhi dan memanipulasi ide-ide sebelum menuangkannya dalam bentuk tulisan. Strategi ini juga membantu siswa dalam mengumpulkan dan mengembangkan ide-ide melalui percakapan terstruktur (Huda, 2014: 218). Beberapa hasil penelitian terdahulu diantaranya oleh Suryadi (2017), Alfianika (2017), Sianturi \& Ambarita (2016) dan Uliana, Dananjaya, \& Primandhika (2019) menunjukkan bahwa strategi Think-Talk-Write berhasil meningkatkan kemampuan menulis siswa.

Permasalahan yang muncul dalam keterampilan menulis teks eksposisi siswa kelas X MIPA 5 SMA Negeri 1 Jalaksana tersebut menjadi landasan peneliti dalam melakukan penelitian tindakan kelas. Penelitian ini bertujuan untuk meningkatkan keterampilan menulis teks eksposisi menggunakan strategi Think-Talk-Write (TTW) pada siswa kelas X MIPA 5 SMA Negeri 1 Jalaksana. Strategi pembelajaran Tbink-Talk-Write diharapkan dapat mendorong siswa untuk berpikir dan mengeluarkan gagasan maupun ide-ide yang siswa miliki dalam belajar menulis teks eksposisi.

\section{Metode Penelitian}

Jenis penelitian yang digunakan oleh peneliti dalam penelitian ini yaitu Penelitian Tindakan Kelas (PTK). Fokus penelitian ini adalah untuk meningkatkan kemampuan menulis teks eksposisi yang berorientasi pada setting pembelajaran menggunakan strategi pembelajaran Think-Talk-Write. Kemmis dan Taggart (dalam Arikunto 2010: 138), menguraikan bahwa rangkaian penelitian tindakan kelas adalah perencanaan, pelaksanaan tindakan, pengamatan, dan refleksi. 
Responden yang menjadi subjek penelitian adalah siswa kelas X MIPA 5 SMA Negeri 1 Jalaksana dengan masalah yang diteliti yaitu kemampuan menulis teks eksposisi. Penentuan kelas didasarkan pada tingkat permasalahan yang ada sesuai dengan hasil wawancara dengan guru yang dilakukan sebelum penelitian yaitu, masih sulitnya siswa untuk mencari ide untuk dikembangkan menjadi tulisan yang utuh, kurangnya pengetahuan siswa tentang teks eksposisi, minimnya penguasaan kosakata siswa, serta sebagian besar siswa di kelas belum memenuhi nilai KKM. Pengambilan objek penelitian ini mencakup proses pembelajaran menulis teks eksposisi dan penilaian kemampuan menulis teks eksposisi siswa kelas X MIPA 5 SMA Negeri 1 Jalaksana . Objek peristiwa yang berupa proses adalah pelaksanaan proses pembelajaran menulis teks eksposisi dengan menggunakan Think-Talk-Write di kelas X MIPA 5 SMA Negeri 1 Jalaksana. Objek hasil atau produk penelitian adalah skor yang diperoleh siswa selama pelaksanaan pembelajaran menulis teks eksposisi dengan menggunakan strategi pembelajaran Think-Talk-Write.

Teknik analisis data yang digunakan dalam PTK ini adalah teknik analisis deskriptif kualitatif. Teknik analisis data dalam penelitian ini dilihat dari analisis proses dan analisis hasil. Analisis proses diambil pada waktu pembelajaran menulis teks eksposisi menggunakan strategi pembe-lajaran Think-Talk-Write dilaksanakan. Analisis hasil dilaksanakan pada saat siswa mengumpulkan hasil menulis teks eksposisi.

\section{Hasil dan Pembahasan}

Berdasarkan hasil pembelajaran yang telah dilaksanakan pada siklus I dan siklus II, diketahui bahwa terjadi peningkatan keterampilan dalam menulis teks eksposisi dan perubahan perilaku belajar siswa ke arah yang lebih positif setelah mengikuti proses pembelajaran menulis teks eksposisi dengan strategi Think Talk Write.

1. Peningkatan Keterampilan Siswa dalam Menulis Teks Eksposisi

Pembahasan peningkatan keterampilan siswa dalam menulis teks eksposisi didasarkan pada hasil tes menulis teks eksposisi yang dilakukan pada siklus I dan siklus II. Sebelum dilakukan tes menulis teks eksposisi dengan menerapkan strategi Think Talk Write, terlebih dahulu dilakukan tes untuk mengetahui seberapa besar keterampilan awal siswa dalam menulis teks eksposisi.

Untuk mengetahui peningkatan keterampilan siswa dalam menulis teks eksposisi setelah pembelajaran menulis teks eksposisi dengan strategi Think Talk Write, maka dilakukan tes keterampilan menulis teks eksposisi siklus I dan siklus II. Hasil tes pada siklus I dan siklus II juga akan dibandingkan dengan hasil tes kondisi awal yang dilakukan guru mata pelajaran, untuk mengetahui perubahan keterampilan siswa dari kondisi awal hingga setelah dilakukan pembelajaran menulis teks eksposisi dengan strategi Think Talk Write.

Berikut ini uraian peningkatan keterampilan siswa dalam menulis teks eksposisi dari hasil siklus I dan siklus II.

Tabel 1. Perbandingan Nilai Rata-Rata Tes Keterampilan Menulis Teks Eksposisi

\begin{tabular}{lccc}
\hline & Rata-rata & \multicolumn{2}{c}{ Peningkatan } \\
SI & SII & SI-SII & $\%$ \\
\hline 77,42 & 84,06 & 6,64 & 18,44 \\
\hline
\end{tabular}


Tabel di atas merupakan tabel perbandingan nilai rata-rata tes keterampilan menulis teks eksposisi masing-masing siklus. Dari tabel di atas, dapat diketahui peningkatan keterampilan siswa dalam menulis teks eksposisi dari siklus I ke siklus II. Hasil tes pada siklus I, dan siklus II digunakan untuk mengetahui peningkatan keterampilan siswa dalam menulis teks eksposisi setelah dilakukan pembelajaran menulis teks eksposisi dengan menerapkan strategi ThinkTalk-Write. Hasil tes menunjukkan nilai rata-rata tes keterampilan menulis teks eksposisi siklus I sebesar 77,42 sedangkan hasil tes keterampilan menulis teks eksposisi siklus II menunjukkan nilai ratarata sebesar 84,06. Dari hasil tersebut dapat diketahui peningkatan keterampilan siswa dalam menulis teks eksposisi dari siklus I ke siklus II sebesar 6,64 poin atau 18,44 \%.

Peningkatan nilai rata-rata tes keterampilan menulis teks eksposisi siklus I dan siklus II dapat dilihat pada diagram berikut.

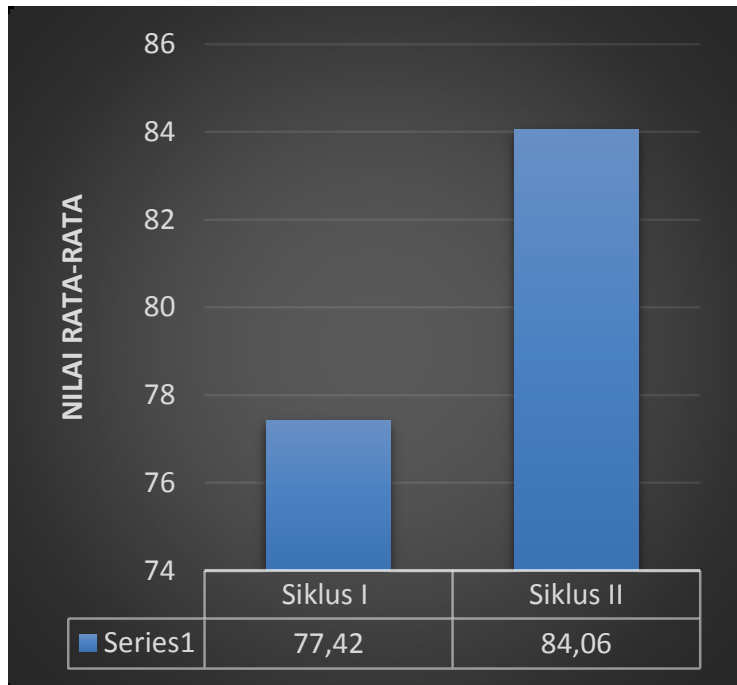

Gambar 1. Rata-rata Nilai Tes Keterampilan Menulis

Agar lebih jelas perbandingan hasil tes menulis teks eksposisi siklus I dan siklus II maka dapat dilihat dari perbandingan nilai rata-rata pada tiap aspek penilaian sebagai berikut.

Tabel 2. Perbandingan Nilai Tiap Aspek Tes Keterampilan Menulis Teks Eksposisi

\begin{tabular}{llcccc}
\hline \multirow{2}{*}{ No. } & \multirow{2}{*}{ Aspek } & \multicolumn{2}{c}{ Rata-rata } & \multicolumn{2}{c}{ Peningkatan } \\
& & Siklus I & Siklus II & SI - SII & $\%$ \\
\hline 1. & Isi & 17,78 & 19,47 & 1,69 & 4,69 \\
2. & Organisasi & 22,03 & 23,97 & 1,94 & 5,39 \\
3. & Kosakata & 15,28 & 16,56 & 1,28 & 3,56 \\
4. & Penggunaan kalimat & 7,39 & 8,08 & 0,69 & 1,92 \\
5. & Mekanik & 14,93 & 15,97 & 1,04 & 2,89 \\
\hline
\end{tabular}

Tabel di atas menunjukkan perbandingan hasil tes keterampilan menulis teks eksposisi pada tiap aspek penilaian. Aspek yang pertama adalah aspek isi. Setelah dilakukan pembelajaran menulis teks eksposisi dengan menerapkan strategi Think-Talk-Write, diperoleh nilai sebesar 17,78. Adapun siklus II memperoleh nilai sebesar 19,47. Dari hasil tersebut dapat 
disimpulkan bahwa terjadi peningkatan keterampilan siswa pada aspek isi dari siklus I ke ke siklus II sebesar 1,69 poin atau 4,69\%.

Aspek yang kedua adalah organisasi karangan. Setelah dilakukan pembelajaran menulis teks eksposisi dengan menerapkan strategi Think-Talk-Write terjadi peningkatan pada siklus I dan siklus II. Pada siklus I nilai rata-rata pada aspek ini sebesar 22,03 dan pada siklus II sebesar 23,97. Dari hasil tersebut dapat diketahui bahwa terjadi peningkatan nilai dari siklus I ke siklus II sebesar 1,94 poin atau 5,39\%.

Aspek yang ketiga adalah aspek kosakata. Pada tes siklus I dan siklus II, setelah dilakukan pembelajaran menulis teks eksposisi dengan menerapkan strategi Think-Talk-Write, pencapaian nilai rata-rata pada aspek kosakat pada siklus I nilai rata-rata mencapai 15,28 dan turun pada siklus II menjadi 16,56. Penurunan nilai rata-rata dari siklus I ke siklus II sebesar 1,28 poin atau $3,56 \%$.

Aspek yang keempat adalah aspek penggunaan kalimat. Pada aspek ini, dari hasil tes diperoleh nilai rata-rata sebesar 7,39 pada siklus I dan sebesar 8,08 pada siklus II. Dari hasil tersebut dapat diketahui bahwa terjadi peningkatan hasil tes menulis teks eksposisi dengan menerapkan strategi Think-Talk-Write. Peningkatan hasil tes siklus I ke siklus II sebesar 0,69 poin atau $1,92 \%$.

Aspek penilaian yang terakhir adalah aspek mekanik. Dari hasil tes diperoleh nilai ratarata siklus I sebesar 14,93 dan 15,97 pada siklus II. Dari hasil tersebut dapat diketahui adanya peningkatan nilai pencapaian pada aspek mekanik. Peningkatan nilai rata-rata dari siklus I ke siklus II sebesar 1,04 poin atau 2,89\%. Agar terlihat jelas perbandingan peningkatan antara siklus I dan siklus II dapat dilihat pada diagram berikut.

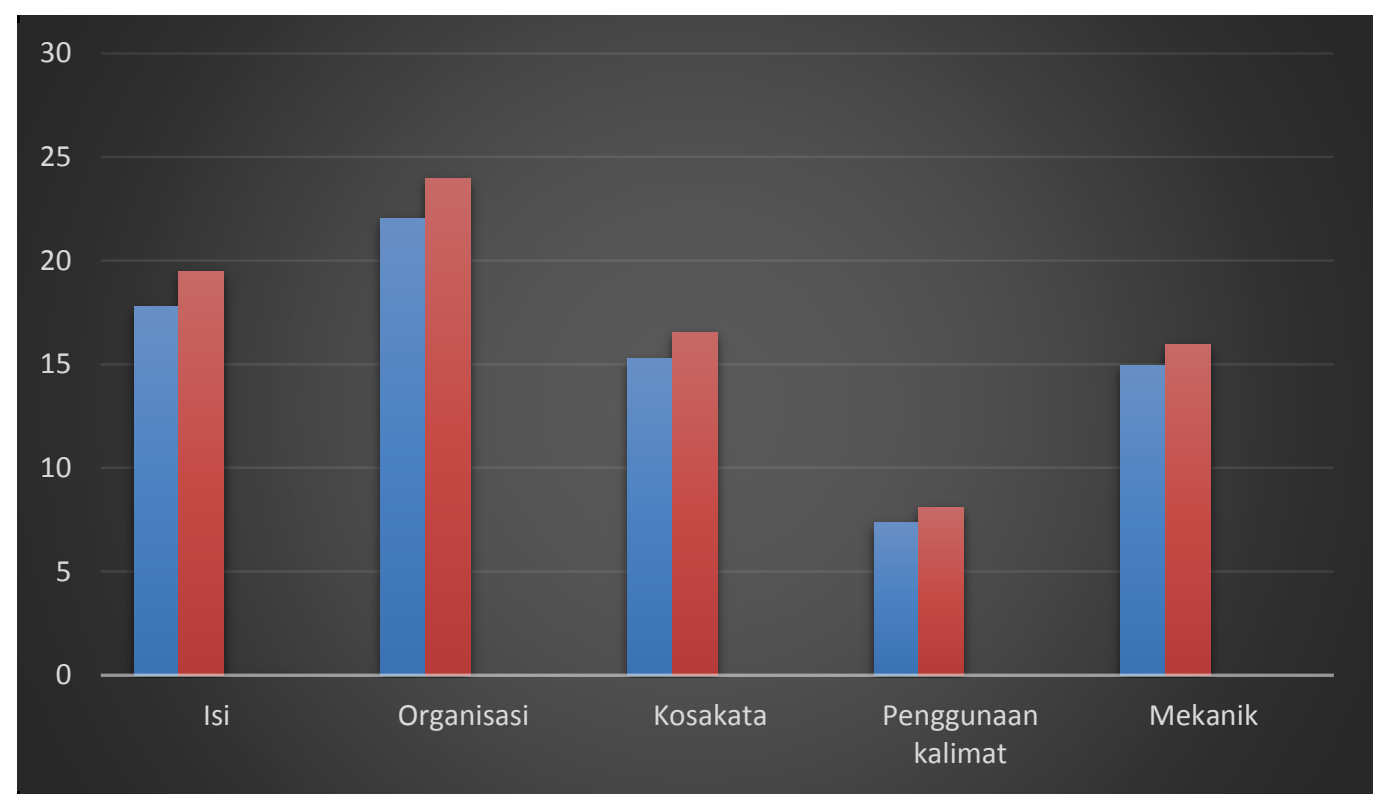

Gambar 2. Perbandingan Peningkatan Antara Siklus I dan Siklus II

Dari hasil pembahasan tersebut dapat ditarik kesimpulan bahwa terjadi peningkatan keterampilan pada siswa X MIPA 5 SMA Negeri 1 Jalaksana dalam menulis teks eksposisi setelah dilakukan pembelajaran pembelajaran menulis teks eksposisi dengan menerapkan strategi Think-Talk-Write. 


\section{Simpulan}

Berdasarkan data-data, analisis dan pembahasan dalam penelitian yang telah diuraikan, maka peneliti mengambil kesimpulan bahw: (1) Strategi Think-Talk-Write merupakan strategi pembelajaran yang menuntut keaktifan proses siswa dalam menulis teks eksposisi. Strategi ini diterapkan dalam pembelajaran dengan tiga tahap; pertama proses think, yaitu siswa diintruksikan untuk membentuk kelompok kecil kemudian membaca dan membuat catatan secara individu. Kedua tahap talk atau berbicara, yaitu berinteraksi dalam grup untuk membahas catatan kecil yang telah didiskusikan sebelumnya. Ketiga tahap write, yaitu konstruksi dari tahap think dan write. Strategi ini diterapkan dalam dua siklus pada kelas $\mathrm{X}$ MIPA 5 SMA Negeri 1 Jalaksana. Setelah strategi ini diterapkan, dalam proses belajar mengajar terbukti keterampilan siswa dalam menulis teks eksposisi meningkat.

Keterampilan menulis teks eksposisi pada siswa kelas X MIPA 5 SMA Negeri 1 Jalaksana mengalami peningkatan setelah dilakukan pembelajaran menulis teks eksposisi dengan strategi Think-Talk-Write. Hasil tes menulis teks eksposisi pada siklus I menunjukkan nilai rata-rata 77,42 dan pada siklus II menunjukkan nilai rata-rata 84,06. Dari hasil tersebut dapat diketahui peningkatan keterampilan siswa dalam menulis teks eksposisi dari siklus I ke siklus II sebesar 6,64 poin atau 18,44\%. Hasil belajar mengajar selain peningkatan keterampilan, Perilaku siswa kelas X MIPA 5 SMA Negeri 1 Jalaksana juga mengalami perubahan ke arah yang lebih positif setelah dilakukan pembelajaran menulis teks eksposisi dengan strategi Think-Talk-Write. Perubahan-perubahan tingkah laku siswa ini dapat dibuktikan dari hasil data nontes yang berupa observasi, jurnal, dan wawancara. Perubahan tingkah laku siswa dapat dilihat secara jelas pada saat pembelajaran. Berdasarkan hasil data nontes pada siklus I masih tampak tingkah laku negatif saat pembelajaran berlangsung. Pada siklus II tingkah laku negatif siswa semakin berkurang dan tingkah laku positif siswa semakin bertambah.

\section{Daftar Pustaka}

Alfanika, N. (2017). Pengaruh Penggunaan Teknik Think Talk Write (Ttw) Terhadap Kemampuan Menulis Cerpen Siswa Kelas X SMA N 1 Painan. Jurnal Gramatika, 3(1), 101-118

Alwasilah, A. Chaedar dan Senny Suzanna Alwasilah. (2007). Pokoknya Menulis. Bandung: PT Kiblat Buku Utama.

Arikunto, Suharsimi. (2010). Prosedur Penelitian Suatu Pendekatan Praktik. Jakarta: Rineka Cipta.

Cintiandini, A., Nahdi, D. S., \& Susilo, S. V. (2019). Mengembangkan Keterampilan Menulis Puisi Siswa Melalui Metode Pembelajaran Tipe Estafet Writing. Prosiding Seminar Nasional Pendidikan FKIP Universitas Majalengka, 146-153. Retrieved from http:// prosiding.unma.ac.id/index.php/semnasfkip/article/view/21

Hamdayama, J. (2014). Model Dan Metode Pembelajaran Kreatif Dan Berkarakter. Bogor: Ghalia Indonesia.

Iru, L \& Arihi L.S. (2012). Analisis Penerapan Pendekatan, Metode, Strategi, dan Model-model Pembelajaran. Jogjakarta : Multi Presindo.

Hamzah, B. (2009). Model Pembelajaran. Menciptakan Proses Belajar Mengajar yang Kreatif dan Efektif. Jakarta: Bumi Aksara.

Hairuddin; Puspita; E.; Mirizon,S.; Zahra. (2007). Pembelajaran Bahasa Indonesia. Jakarta: Direktorat Jenderal Pendidikan tinggi Departemen Pendidikan Nasional. 
Helmawati, Raja, P \& Samhati, S. (2015). Peningkatan Kemampuan Menulis Melalui Pendekatan Saintifik Pada Peserta Didik SMA. J-Simbol Bahasa, Sastra, dan Pembelajarannya), 2 (1), 1-13.

Huda, M. (2013). Model-Model Pengajaran Dan Pembelajaran. Pustaka Jaya: Yogyakarta.

Ibrahim, AS \& Wahyuni, S. (2012). Asesmen Pembelajaran Babasa. Bandung: PT Reika Aditama.

Kuncoro, M. (2009). Mahir Menulis. Erlangga: Jakarta.

Rohmadi, M. \& Nugraheni, S. (2011). Belajar Bahasa Indonesia Upaya Terampil Berbicara dan Menulis Karya Ilmiah. Surakarta: Cakrawala Media.

Sianturi, EO. \& Ambarita, B. (2016). Pengaruh Model Pembelajaran Think Talk Write (Ttw) Terhadap Kemampuan Menulis Puisi Oleh Siswa Kelas X SMA Negeri 14 Medan Tahun Pembelajaran 2015/2016. Basastra, 5(2), 1-12.

Suryadi, A. (2017). Penerapan Model Pembelajaran Think Talk Write (Ttw) Untuk Meningkatkan Kemampuan Menulis Karangan Deskripsi Siswa Kelas V SDN Ketintang II/410 Surabaya. Jurnal Penelitian Pendidikan Guru Sekolah Dasar, 5(3), 1582-1596.

Uliana, I. Dananjaya, HF. \& Primandhika, RB. (2019). Penerapan Metode Think Talk Write Dalam Pembelajaran Menulis Teks Cerpen Pada Siswa Menengah Atas. Parole (Jurnal Pendidikan Bahasa Dan Sastra Indonesia), 2 (4), 495-500.

Yunsirno. (2010). Keajaiban Belajar. Pontianak: Pustaka Jenius Publishing. 